\title{
Work and Family Conflict: The Case of Women in the Turkish Health Sector
}

\author{
Prof. Dr. Ömer Çaha (Istanbul Sabahattin Zaim University, Turkey)
}

\begin{abstract}
This study focuses on employment status and mobilization processes of women at 102 hospitals in 12 provinces of Turkey. The main question of the research is whether women face glass ceiling problem at hospitals, which are the locomotive stations of the healthcare sector. According to research findings based on institutional analysis, questionnaires and in-depth interviews, there is an obvious glass ceiling problem at hospitals. Although the proportion of women working at hospitals is higher than that of men, there are more men at administrative level than women. In this respect, no significant difference has been found between private hospitals and public hospitals. In both sectors, women clearly fall behind men regarding mobilization processes. This is due to working conditions and social relations within hospitals as well as personal preferences.
\end{abstract}

\section{Literature Review}

Women, nowhere in the world, have the same opportunities as men to rise at work. There are a number of visible or invisible obstacles that obstruct women in respect to mobilization process. In the literature, this is called "glass ceiling syndrome" (Elliott and Smith, 2004). The glass ceiling is a global problem and is a barrier that women face in work life all over the world (Weyer, 2006). This barrier is not a measurable or visible one such as educational level or work experience (Powell and Butterfield, 2003). The term "glass", refers to invisible and unpassable obstacles (Hoobler et al., 2009).

There are many factors that prevent women from rising at work. These might be summarized under three headings: Personal, institutional and social factors. Personal preference (White, et. al., 1992), self-doubt and double responsibility (Laughlin, 2011) are among the personal barriers to the rise of women. They cannot get rid of their family responsibilities even when they get mobilized to managerial positions in business life. As reported by veral researches, women prioritize family life over work and they make their career plans accordingly. This causes women to take on lower positions as a personal preference (Thompson and Cavallaro, 2007).

There are a multitude of institutional factors that prevent the rise of women in business life. Organizational culture, institutional policies, lack of consultancy, difficulties in participating in informal communication networks, mobbing in the workplace, discrimination or sexual harassment are the reasons for institutional factors (Froide, 2009). The perception that the managers are male, which is prevalent in the organizational culture, also reflects on the policies of institutions (Klenke, 1996). In working life, informal social relations with persons in effective positions are as important as skill, knowledge and ability in recruitment and promotion processes (Cannings 1988). Informal relations are one of the important means of making progress in career. Such relationships increase visibility, career planning, strategy development and professional support as well as information exchange (Granovetter, 1995; Ibarra, 1993; Moore, 1990). Friendship relations within institutions are often gender-based. Non-work-related social relations with colleagues and supervisors are often formed or strengthened through various activities that take place in the evenings after work or on weekends (Miller, 2004). This causes women to stay out of informal social networks.

Psychological and sexual harassment in the workplace is another reason among the institutional factors preventing women from rising at work and holding on to business life. As reported by the US Department of Labor, 37 percent of employees in the US are exposed to mobbing at work (Lutgen-Sandvik and Sypher, 2007). According to a survey, 40 percent of women exposed to mobbing in the workplace in Sweden were psychologically abused by other women, 30 percent by men, and 30 percent by both sexes (Leyman, 1996).

Another one of the reasons preventing the women from rising in business life is related to gender roles. Sexspecific patterns continuous, and they resist to change. These patterns teach not only beliefs about men and women, but also how they should be (Dodge et al., 1995). The masculine and feminine cultures of societies influence women's status in the work life. According to the researches, there are less barriers to women being managers when the values and norms in a society are closer to the feminine culture (Grosvold, 2011). Societies such as Japan, Austria, Venezuela, Italy, Switzerland and Mexico have masculine cultures, while Norway, Sweden, the Netherlands, Denmark and Finland have a feminine culture, according to a research conducted by G. Hofstede on a total of 11,600 people from 40 countries in 2010. As stated in Hofstede's research, masculine and feminine cultures do not have any impact upon occupational distribution of women and men, whereas women living in countries with feminine cultures are more likely to work in technical jobs and learned professions (Hofstede and Minkov, 2010).

In short, women are expected to care for children, elderly and patients at home, as well as they are supposed to be sensitive and polite, for they are socialized in accordance with their gender roles. Besides, they are expected to 
prefer occupations such as teacher, nurse, secretary, and customer representative when they work. However, values such as strong, powerful, ambitious, courageous, and independent which gender roles attribute to men lead men to tend to professions such as soldier, engineer, merchant and administrator (Dökmen, 2004). As a consequence of cultural patterns, women concentrate in low-wage and relatively low prestigious sectors and fields, while men concentrate in prestigious professions with high income.

As mentioned above, the glass ceiling problem is a global problem and is seen in every country in one way or another. Despite the fact that the rate of female students receiving business education in the US is 57 percent, the ratio of women in the top management of the enterprises is too small. There are no female executives in 10 percent of the largest five hundred companies in the United States, while 25 percent have three or four female executives in total (Catalyst, 2013). In the United States, the percentage of senior female executives in banking and financial institutions that are known as sectors in which women concentrate is around 12 percent and in the health sector it is around 14 percent (Ellemers et. al., 2012).

To overcome this problem, some European countries have introduced quotas. In countries where quotas are applied, the proportions are not the same as men, albeit relatively better for women. In Norway, where the quota is mandatory, the proportion of female managers is 36 percent, while in Sweden and Finland it is 27 percent. Despite strict legal regulations in recent years, the female executive rate in France has not exceeded 18 percent. Japan has the worst performance in terms of the level of female executive among developed countries. In Japan, the proportion of female executives is only 1 percent. Developing or underdeveloped countries are in a much worse state than developed countries in this regard. In developing countries, the average proportion of senior female executives is around 7 percent (The Guardian, 2013).

\section{Women in Turkish Health Sector}

Women's employment in Turkey concentrates in mainly four sectors: health, education, finance and telecommunication. There are people from various professions with different qualifications in the health sector. According to data from the Ministry of Health, the number of healthcare workers in 2002 increased from 378,551 to 735,159 in 2013.

In the health sector, various health professionals, such as physicians, nurses, midwives, technicians, who need to get vocational training for a long time and cannot be substituted with other professional groups, are working. This leads the sector to always have difficulties having enough number of employees (Belek 2001).

Within the scope of the health transformation program that was held in Turkey in 2003, which paved the way for providing private medical service, the number of private hospitals and polyclinics has increased rapidly (Yildırım, 2013). According to the 2013 data, there are 413 private clinics and 913 medical centers in Turkey (Sağlık Bakanlığı, 2014). In 2013, the total number of physicians working in the private sector was 28,466 , the number of nurses and midwives was 25,718 and the number of other health personnel was 26,393 . The total number of people working in the private health care sector was 139,933, accounting for 19 percent of the total employment in the health sector (Ibid).

In the health sector, the number of physicians increased from 72,393 in 2002 to 139,544 in 2013 and the number of nurses increased from 83,964 to 224,618 (Sağlık Bakanlığı, 2014). The proportion of female physicians employed in the Ministry of Health and university hospitals is 34 percent. Due to the increase in the ratio of female students studying at the medical faculties, the occupation of physicians is expected to be a more female-oriented profession in the coming years (Kuzucu, 2007). In the health sector, women constitute 72 percent of auxiliary staff such as laborants and health technicians; 63 percent of office workers and customer service employees and 51 percent of service and sales staff. In these occupations defined as auxiliary staff, there is no chance for women to rise (Urhan and Etiler, 2011).

In 2013, the number of physicians per hundred thousand people is 325 in EU member states, while 174 in Turkey (Sağlı Bakanlığ 1,2014 ). These data indicate that the number of physicians in Turkey is quite inadequate compared to the EU countries. The number of nurses and midwives per hundred thousand people is 869 in developed countries and 836 in EU countries whereas it is only 252 in Turkey (Ibid). In the health sector, there is a shortage of midwives and nurses. For this reason, the workload of midwives and nurses is extremely heavy. The health sector inherently requires working at nights and holidays. Thus, there are different types of shifts in the sector (Ekici and Özçelik, 2011). This poses problems for women working in the sector.

\section{Research Method}

The main subject of the present study is the problems faced by women working in the health sector in Turkey and the obstacles to their rise at work. The study was conducted on women who work in various positions at hospitals. In this context, hospital managers, chief physicians, doctors, nurses, technical staff, civil servants and midwives were included. The research mainly focuses on the problems that women working in these institutions 
have due to family, social environment and business environment; and the difficulties they face during the promotion process.

Our research was conducted in 102 hospitals in 12 provinces and districts selected according to the NUTS2 zoning system. The research was designed based on three methods. These are respectively institutional analysis, questionnaires based on face-to-face interviews and in-depth interviews.

In hospitals evaluated within the institutional analysis, the number of personnel in total, the number of female personnel and the positions in which women work, were investigated. Information on this subject was gathered through interviews with the institution's managers and questionnaires made at the institutional level. In this context, it was also searched whether there is a difference between the private sector and the public sector in terms of gender distribution and the glass ceiling problem at 102 hospitals included in the study.

Secondly in the research, a comprehensive questionnaire was answered by women working at 102 hospitals, who were selected with stratified and simple random sampling technique. 10 women from each hospital working in different positions, were included in the study. The survey included a total of 1020 woman working in different positions such as doctors, nurses, technicians, secretaries, civil servants and midwives. In the questionnaire, it was mainly aimed to determine the problems caused by the family, the social environment and the business environment, and to what extent these problems are reflected in the working life.

\begin{tabular}{|l|c|c|c|}
\hline & Number of Hospitals & Number of Respondents & Percent \\
\hline Ankara & 12 & 120 & 11,8 \\
\hline Antalya & 8 & 80 & 7,8 \\
\hline Bursa & 8 & 80 & 7,8 \\
\hline Diyarbakir & 6 & 60 & 5,9 \\
\hline Edirne & 6 & 60 & 5,9 \\
\hline Erzurum & 6 & 60 & 5,9 \\
\hline İstanbul & 16 & 160 & 15,7 \\
\hline İzmir & 12 & 120 & 11,8 \\
\hline Kayseri & 8 & 80 & 7,8 \\
\hline Samsun & 8 & 80 & 7,8 \\
\hline Trabzon & 6 & 60 & 5,9 \\
\hline Van & 6 & 60 & 5,9 \\
\hline Total & $\mathbf{1 0 2}$ & $\mathbf{1 0 2 0}$ & $\mathbf{1 0 0}$ \\
\hline
\end{tabular}

Table 1. Sample Distribution

Thirdly, in-depth interviews were conducted face-to-face with hospital managers. Interviews were carried out in seven provinces, one in each geographical region. These are Ankara, Istanbul, Izmir, Diyarbakir, Antalya, Samsun and Van. Interviewees consisted of 10 male and 10 female managers.

The main subjects of the interviews are the comparison of the performances of women at work with men, the satisfaction level of women workers, the problems that women employees face and the obstacles to their rise at work in the eyes of managers. The reason for including male directors in interviews was to compare both of the genders' outlooks on the problem. The research findings are based on the data acquired in three ways.

The area study of the research was conducted between March 2014 and October 2015.

\section{Research Findings}

The present research focuses on two main problems: the ratio of men and women in hospital administration and the attitudes of women to the executives as well as their own working conditions. From this point of view, the research findings are also planned to provide analysis for these two subjects separately.

\subsection{The Glass Ceiling Problem at Hospitals}

Table 1 shows the total number of female and male staff working at hospitals. As can be seen in the table, there are more than 50 thousand personnel working in different positions at hospital. Some of the hospitals that are included in the research employ more than a thousand staff, while others have the capacity to employ about 100 only. Particularly, private hospitals prefer to serve with fewer staff than state hospitals. 


\begin{tabular}{|l|c|c|c|}
\hline & Female & Male & Total \\
\hline Hospital manager & 14 & 81 & 95 \\
\hline Assistant hospital manager & 70 & 120 & 190 \\
\hline Chief physician & 12 & 90 & 102 \\
\hline Chief physician assistant & 51 & 178 & 229 \\
\hline Administrative financial manager & 22 & 79 & 101 \\
\hline Administrative financial manager assistant & 41 & 117 & 158 \\
\hline Medical services manager & 61 & 37 & 98 \\
\hline Medical services manager assistant & 62 & 67 & 129 \\
\hline Physician & 7029 & 8334 & 15363 \\
\hline Nurse/civil servant & 19775 & 10499 & 30274 \\
\hline Technician & 1289 & 2305 & 3594 \\
\hline Total & $\mathbf{2 8 4 2 6}$ & $\mathbf{2 1 9 0 7}$ & $\mathbf{5 0 4 3 5}$ \\
\hline
\end{tabular}

Table 2. Vocational Distribution of those Included in the Research

According to research findings, the proportion of women working in different positions at the 102 hospitals is significantly higher than males (56 to 44 percent). However, as seen in Table 4 , the proportion of women in administrative positions such as hospital manager, chief physician and chief physician assistant is significantly lower than that of men.

\begin{tabular}{|l|c|c|}
\hline & $\mathbf{N}$ & $\mathbf{\%}$ \\
\hline Female & 28442 & 56,4 \\
\hline Male & 21993 & 43,6 \\
\hline Total & $\mathbf{5 0 4 3 5}$ & $\mathbf{1 0 0}$ \\
\hline
\end{tabular}

Table 3. Gender Distribution of Employees

The hospitals are administered by a manager according to a regulation brought in about the hospitals during the dates of the research. In the previous regulation, the main authority in the hospital was the chief physician. However, the new regulation gives full authorization to the hospital managers regarding all the hospital operations, while assigning the health care services to the chief physician. Some of the private hospitals do not have a manager. The role of the manager has been taken on by the owner of the hospital or the chairman of the executive board. In the study, to investigate the glass ceiling problem, a question was asked about who the hospital managers consist of. As shown in Table 4, only 14 percent of hospital managers are women. Approximately 7 percent of the hospitals included in the research do not have any managers. It is significant to remember that the hospitals where there is no manager are mostly private hospitals. Based on these data, we can say that there is noticeably a glass ceiling problem at the managerial level at hospitals.

\begin{tabular}{|l|c|c|c|}
\hline & Hospital Manager & Chief Physician & Chief Physician Assistant \\
\hline Female & 13,7 & 11,8 & 22,3 \\
\hline Male & 79,4 & 88,2 & 77,7 \\
\hline None & 6,9 & & $\mathbf{1 0 0}$ \\
\hline Total & $\mathbf{1 0 0}$ & $\mathbf{1 0 0}$ & $\mathbf{1 0 0}$ \\
\hline
\end{tabular}

Table 4. Gender Distribution at Senior Management Level

A similar situation is seen at the level of chief physicians regarding the glass ceiling syndrome at hospitals. As shown in Table 4, only about 12 percent of the chief physicians are women and 88 percent are men. The proportion of women at the level of chief physician assistant nearly doubles that of position of chief physician (22 percent). Senior bureaucrats or politicians in the health sector decide who are to be the chief physicians at public hospitals. In the private sector, this decision naturally belongs to employers. Therefore, it would not be wrong to say that the head office in the public sector is determined through high-level references.

A male chief physician, one of the interviewees (T. T., 2014), expressed this assessment as follows:

"There are very qualified female physicians who have strong personality, can be influential and manage the hospital. However, they must have high-level references to be able to reach the senior management positions."

However, this is not the case for the position of chief physician assistant. On this point, performance is more involved. Nonetheless, as chief physicians generally determine who are to be the chief assistant, it is easier for women to take more places in these positions. 


\begin{tabular}{|l|c|c|}
\hline & Administrative Financial Manager & Medical Services Manager \\
\hline Female & 22,6 & 59,8 \\
\hline Male & 77,4 & 36,3 \\
\hline None & & 3,9 \\
\hline Total & $\mathbf{1 0 0}$ & $\mathbf{1 0 0}$ \\
\hline
\end{tabular}

Table 5. Gender Distribution in Middle-Level Managerial Positions

During the interviews, it was stated that women concentrate more in the middle level management positions in the health sector. The data shown in Table 5 confirms this statement. Likewise, it is seen that 60 percent of the managers in the units related to medical services are women. One of the research participants expressed this point:

"Monetary affairs, appointments, that is, affairs with institutions such as the Ministry and SGK (Social Security Institution) are managed by the senior management, which is dominated by men. Nevertheless, positions in middlelevel management are dominated by women. Because, in this regard, not women's authority, but their expertise is of importance" (Same participant).

Starting from these data, one can assume that reaching the senior management level is not performance oriented but it is determined by the senior bureaucracy, politics or business circles. These preferences, as the research findings reveal, are disadvantageous to women. However, in areas where expertise is required, women may take up more positions depending on their qualifications.

\begin{tabular}{|l|c|c|c|c|c|c|}
\hline & \multicolumn{2}{|c|}{ Hospital Manager } & \multicolumn{2}{c|}{ Chief Physician } & \multicolumn{2}{c|}{ Chief Physician Assistant } \\
\hline & Public & Private & Public & Private & Public & Private \\
\hline Female & 13,0 & 16,3 & 15,7 & 7,8 & 19,2 & 28,8 \\
\hline Male & 87,0 & 83,7 & 84,3 & 92,2 & 80,8 & 71,2 \\
\hline Total & $\mathbf{1 0 0}$ & $\mathbf{1 0 0}$ & $\mathbf{1 0 0}$ & $\mathbf{1 0 0}$ & $\mathbf{1 0 0}$ & $\mathbf{1 0 0}$ \\
\hline
\end{tabular}

Table 6. Sectoral Distribution of Senior Management Positions

Is there a meaningful difference in the rate of female managers between public hospitals and private hospitals regarding the positions of hospital manager, chief physician and chief physician assistant? As shown in Table 6, proportion of women at the hospital manager level is higher at private hospitals. At private hospitals, the proportion of female managers is 3 percent higher than public hospitals. Despite different rates seen between the two sectors it seems that this difference is not statistically significant $(\mathrm{P}=.656, \mathrm{P} \geq .05)$. In other words, there is not statistically enough difference between public hospitals and private hospitals in respect to the gender of their managers.

\begin{tabular}{|l|l|l|l|l|l|l|}
\hline & Sector & N & Mean & Std. Deviation & Std. Error Mean & Sig. (2 tailed) \\
\hline \multirow{2}{*}{$\begin{array}{l}\text { Hospital } \\
\text { Manager }\end{array}$} & Public & 46 & 1,13 &, 341 &, 050 & \\
\cline { 2 - 6 } & Private & 49 & 1,16 &, 373 &, 053 & 0,656 \\
\hline \multirow{2}{*}{$\begin{array}{l}\text { Chief Physician } \\
\text { Chief Physician }\end{array}$} & Public & 51 & 1,16 &, 367 &, 051 & \multirow{2}{*}{0,223} \\
\cline { 2 - 6 } \begin{tabular}{l} 
Assistant \\
\cline { 2 - 5 }
\end{tabular} & Private & 51 & 1,08 &, 272 &, 038 & 0,355 \\
\cline { 2 - 5 } & Public & 51 & 1,20 &, 401 &, 056 &, 063 \\
\hline
\end{tabular}

Table 7. Statistical Analysis of Gender Distribution in Senior Management Positions

According to results of the investigation regarding the chief physician level, the proportion of female chief physicians is higher at public hospitals than private hospitals. There is a difference of about 8 percent between the two. However, this difference seems not to be statistically significant $(\mathrm{P}=.223, \mathrm{P} \geq .05)$. At the level of chief physician assistant, it is seen that the number of female chief physician assistants at private hospitals is proportionally higher than that of public hospitals. But, there is no statistically significant difference between public and private hospitals in that respect $(\mathrm{P}=.355, \mathrm{P} \geq .05)$.

\begin{tabular}{|l|c|c|c|c|}
\hline & \multicolumn{2}{|c|}{$\begin{array}{c}\text { Administrative } \\
\text { Financial Manager }\end{array}$} & \multicolumn{2}{c|}{$\begin{array}{c}\text { Medical Services } \\
\text { Manager }\end{array}$} \\
\hline & Public & Private & Public & Private \\
\hline Female & 14,0 & 29,4 & 65,3 & 59,2 \\
\hline Male & 86,0 & 70,6 & 34,7 & 40,8 \\
\hline Total & $\mathbf{1 0 0}$ & $\mathbf{1 0 0}$ & $\mathbf{1 0 0}$ & $\mathbf{1 0 0}$ \\
\hline
\end{tabular}

Table 8. Gender Distribution in Middle-Level Management Positions

A similar assessment is also relevant for mid-level management staff. The performance of private hospitals regarding the position of administrative financial manager seems to be proportionally higher than public hospitals. 
But according to the result of t-test analysis this difference is not statistically significant $(\mathrm{P}=.62, \mathrm{P} \geq .05)$. As to the medical services management, it is apparent that the proportion of women is higher at public hospitals than private hospitals. But the difference between two groups of hospitals is not statistically significant enough $(\mathrm{P}=.537, \mathrm{P} \geq$ $.05)$.

As the results of investigation are apparently indicate, there is not considerable difference between public hospitals and private hospitals in respect to the gender of those who hold the top as well as middle-level managerial positions.

\subsection{Attitudes Towards Working Conditions and Administration}

Regarding the problems faced by women working in the health sector, family responsibility clearly stands out. More than half of the women express that their family responsibilities pose the most important challenge to their career. Besides, social prejudice and unequal treatment of the institution are the other problems. There is no statistically significant difference between the public sector and the private sector $(\mathrm{P}=.656, \mathrm{P} \geq .05)$.

\begin{tabular}{|l|c|c|c|}
\hline & Public & Private & Average \\
\hline Family responsibilities & 53,7 & 53,7 & 53,7 \\
\hline Social prejudices & 18,6 & 18,9 & 18,8 \\
\hline Unequal treatment of institution & 21,8 & 23,6 & 22,8 \\
\hline Other & 5,9 & 3,7 & 4,8 \\
\hline Total & $\mathbf{1 0 0}$ & $\mathbf{1 0 0}$ & $\mathbf{1 0 0}$ \\
\hline
\end{tabular}

Table 9. The Most Important Challenge Faced by Women Working in Health Sector?

One of the questions addressed to the participants was "which gender, they think would manage better". According to the answers to this question, the number of those who think that men would be better managers is more than women thinking that they would be better managers. Percentage of difference between the two is 11 in favor of men. This can be considered in connection with socialization and cultural patterns as mentioned above. This is because the notion that men would be better managers is a mainstream idea in cultural values of Turkish society (Sakall, 2003). There was no statistically remarkable difference between the private and the public sectors in this respect $(\mathrm{P}=.434, \mathrm{P} \geq .05)$.

\begin{tabular}{|l|c|c|c|}
\hline & Public & Private & Average \\
\hline Female & 24,9 & 21,5 & 23,1 \\
\hline Male & 31,4 & 34,3 & 32,9 \\
\hline Both alike & 43,7 & 44,2 & 43,9 \\
\hline Total & $\mathbf{1 0 0}$ & $\mathbf{1 0 0}$ & $\mathbf{1 0 0}$ \\
\hline
\end{tabular}

Table 10. Which Gender Do You Think Would Be Better Managers in Your Profession?

As a follow-up question, it was also asked whether they preferred female or male managers. According to the answer to this question, among the women working at hospital, the percentage of those who prefer male managers is higher than those who prefer the female managers.

There is no major difference between the two, yet it confirms the previous data that is in favor of men. Most women who participated in the survey state that gender of the manager is of no importance to them.

\begin{tabular}{|l|c|c|c|}
\hline & Public & Private & Average \\
\hline Male & 26,7 & 24,3 & 25,5 \\
\hline Female & 23,1 & 22,5 & 22,8 \\
\hline No difference & 50,2 & 53,2 & 51,7 \\
\hline Total & $\mathbf{1 0 0}$ & $\mathbf{1 0 0}$ & $\mathbf{1 0 0}$ \\
\hline
\end{tabular}

Table 11. Which Gender Do You Prefer Your Manager to be; Male or Female?

When examining this on a sectoral basis, it should be noted that there is no statistically considerable difference between the private sector and the public sector in this context. In other words, the attitudes of the women working in both sectors towards the gender of the manager are alike.

\section{Evaluation and Discussion}

Why do women in the healthcare sector not get management positions much? It may well be argued that the three views expressed in the in-depth interviews play a significant role in this respect. First, it would not be wrong say that favoritism based on political tendency, kinship or friendship plays a role in this regard. At public hospitals, senior management is defined by political or higher-level bureaucratic networks. As such, such references can be determining factor for senior management at hospitals. To point out this situation, one of the participants uttered the following statements: 
"In the health sector, to get managerial positions, such as manager and chief physician, is often possible through political connections. You cannot get these positions with your own efforts or your competence " (S. K., 2015).

Secondly, it can be said that priorities of private sector serve a function in this sense. The private sector is profitoriented. Naturally, it aims to get maximum efficiency from the managers. Regarding overtime working and heavy working conditions, men are more flexible than women. This makes men in the private sector more advantageous than women in the managerial positions.

The third reason is that women are not willing to reach the senior management positions which require responsibilities. A hospital administrator (E. Y., 2014) expresses this through following statements:

"Administrators need to spare a lot of time for hospital. They have to work late at nights and come on weekends to attend meetings. Women cannot spare time for their houses when they do it for hospital. And women are not very enthusiastic about being a manager, because they cannot take on heavy responsibilities of management."

A woman (H. S., 2015) who works as a chief physician assistant at a public hospital has confirmed that by stating these:

"They offered me to choose between the positions of chief physician and the assistant. I preferred to be assistant. Being a chief physician both requires a lot of responsibilities and to deal with senior managers. It is very painful to deal with the seniors, and to represent the institution there. Because I did not want to deal with the seniors, I chose to settle for being assistant. There is only one authority above me at the moment. I do not have any trouble. I think I have done well choosing this."

Despite their successful positions in the public space, women continue to play the roles of housewife and motherhood, while maintaining their roles in the public space. The double responsibility that women have to bear makes them fall behind men in terms of management which requires heavy working conditions, responsibilities and intense work. A participant, pointing to the importance of family support, expressed the following opinion on this difficulty:

"You have the capacity to be a manager. But when you go to hospital at night or on weekend, your husband sulks about it. When you want to fulfill the requirements of the managerial position, your husband does not want your promotion to the upper level positions." (Same participant).

In this context, it is meaningful that some women who have reached the top level management are divorced.

\section{Conclusion}

In conclusion, our research reveals that there is distinctly a glass ceiling problem both at public and private hospitals in Turkey. This is evidenced by the fact that women are clearly below males in senior management positions at hospitals. We have found out the importance of two points lying at the root of this problem: Personal preferences due to family responsibility and heavy working conditions and political and bureaucratic connections. Female specialists qualified enough to take part in hospital management prefer middle-level management jobs with less responsibilities rather than coming to senior management positions due to the double burden of family and work responsibilities. But those, who try to overcome these and rise at work, face political and bureaucratic obstacles, though.

\section{References}

* This study is a part of investigation supported by the World Bank and Woman and Democracy Association located in Istanbul. I would like to send my feeling of thanks and appreciation to both institutions.

- Belek İ., 2001. Sosyal Devletin Çöküşü ve Sağlığın Ekonomi Politiği. Sorun Yayınları, İstanbul, p. 33.

- Cannings, K., 1988. “Managerial Promotion: The Effects of Socialization”, Industrial \& Labor Relations Review, 42, (1).

- Catalyst, 2013. Fortune 500 women board directors, http://www.catalyst.org/knowledge/2013-catalystcensus-fortune-500-women-board-directors

- Dodge, K. A. et. al., 1995. "Requisite Management Characteristics Revisited: Two Decades Later", Journal of Social Behavior \& Personality, 10, (6).

- Dökmen, Z. Y., 2004. Toplumsal Cinsiyet: Sosyal Psikolojik Açıklamalar. Sistem Yayıncılık, İstanbul.

- $\quad$ E. Y., 20 August 2014. Interview by Sevim Yüksel Çakmakçı, Antalya.

- $\quad$ Ekici, T., Özçelik, Z., 2011. Hekimlerin Çalişma Süresi, Nöbet, Fazla Çalişma Ücreti, Dinlenme ve İzin Haklari. Türk Tabipler Birliği, Ankara, p. 12. 
- Ellemers, N., et. al., 2012. "Women in High Places: When and why Promoting Women Into Top Positions can Harm them Individually or as a Group (and how to Prevent this)", Research in Organizational Behavior, 32.

- Elliott, J. R., Smith, R. A., 2004. "Race, Gender, and Workplace Wower". American Sociological Review, 16, (69), 365-386.

- $\quad$ Froide, A. M., 2009. “Disciplinary Differences: A Historian’s Take on Why Wages Differed by Gender in Eighteenth and Nineteenth Century Britain”, Social Science History, 33, (4).

- Granovetter, M., 1995. Getting a Job: A Study of Contacts and Careers. The University of Chicago Press, Chicago.

- Grosvold, J., 2011. "Where are all the Women? Institutional Context and the Prevalence of Women on the Corporate Board of Directors", Business \& Society, 50, (3).

- H. Ş., 31 January 2015. Interview by Havva Çaha, Ankara.

- Hofstede, G., Minkov, M., 2010. “Long-Versus Short-term Orientation: New Perspectives”. Asia Pacific Business Review, 4, (16).

- Hoobler, J. M., et. al., 2009. “'Bosses' Perceptions of Family-Work Conflict and Women's Promotability: Glass Ceiling Effects", Academy of Management Journal, 52, (5).

- Ibarra, H., 1993, "Personal Networks of Women and Minorities in Management: A Conceptual Framework", Academy of Management Review, 18, (3).

- Klenke, K., 1996. Women and Leadership: A Contextual Perspective. Springer, New York.

- Kuzucu, İ., 2007. “Türkiye'de Tıpta Uzmanlık ve Akademisyenlik Aşamalarında Cinsiyetçi Yaklaşımlar”, Unpublished MA Thesis, Ankara University, Institute of Social Sciences, Ankara, p. 44.

- Laughlin, L., 2011. "Maternity Leave and Employment Patterns: 2006-2008”, Current Population Report. U.S. Census Bureau, Washington Dc.

- Levinson, D., 1978. The Seasons of a Man's Life. Knopf, New York.

- Leymann, H., 1990. "Mobbing and Psychological Terror at Workplaces", Violence and Victims, 2, (5), p. 175 .

- Lutgen-Sandvik, P., Sypher, B. D., 2007. Destructive Organizational Communication. Routledge, New York, p. 41.

- Miller, G. E., 2004. "Frontier Masculinity in the Oil Industry: The Experience of Women Engineers", Gender, Work and Organization, 11, (1), p. 51.

- Moore, G., 1990. “Structural Determinants of Men's and Women's Personal Networks”, American Sociological Review, 14, (55).

- Powell, G., Butterfield, D., 2003. "Gender, Gender Identity and Aspirations to Top Management”, Women in Management Review, 18, (1-2), p. 89.

- $\quad$ S. K., 31 January, 2015. Interview by Havva Çaha, Ankara.

- Sağlık Bakanlığı, 2014. T.C. Sağlık Bakanlığı, sağlık istatistikleri yıllığı 2013, http://ekutuphane.sagem.gov.tr/kitaplar/saglik_istatistikleri_yilligi_2013.pdf

- Sakallı, U. N., 2003. "Cinsiyetçilik: Kadınlara ve Erkeklere İlişkin Tutumlar ve Çelişik Duygulu Cinsiyetçilik Kuramı”, Türk Psikoloji Yazıları, 6, (11-12).

- $\quad$ T. T., 14 May, 2014. Interview by Bahar Yağc1, Ankara.

- The Guardian, 2013. More women in business makes for better business overall, https://www.theguardian.com/.../women-better-for-business.

- Thompson, B. M., Cavallaro, L., 2007. “Gender, Work-Based Support and Family Outcomes”. Stress and Health, 23, (2).

- Urhan, B., Etiler, N., 2011. "Sağlık Sektöründe Kadın Emeğinin Toplumsal Cinsiyet Açısından Analizi”, Çalışma ve Toplum, 1, (2), p. 202.

- Weyer, B., 2006. "Do Multi-Source Feedback Instruments Support the Existence of a Glass Ceiling for Women Leaders?", Women in Management Review, 21, (6), p. 442.

- White, B., Cox, C., Cooper, C., 1992. Women's Career Development: A Study of High Flyers. Blackwell Publishers, Oxford, p. 126.

- Yildırım, H. H., 2013. Türkiye Sağlik Sistemi: Sağlikta Dönüşüm Programı Değerlendirme Raporu. Sağlık Sen Yayınları, Ankara, p. 25. 